\title{
The Protection of Rights to Education for the Refugee Children during the Covid-19 Pandemic
}

\author{
Fithriatus Shalihah ${ }^{1}$, Uni Tsulasi Putri ${ }^{2}$ \\ ${ }^{1,2}$ Universitas Ahmad Dahlan, Yogyakarta - Indonesia \\ E-mail: fithriatus.shalihah@law.uad.ac.id/uni.putri@law.uad.ac.id
}

\begin{abstract}
Child as the smalles member in family is the main vulnarable actor. Internationally speaking, the protection of children's rights is granted under the Convention on the Rights of the Children. One of the most crucial children righs to be concerned is the right to education in a non-discriminatory manner. The Covid-19 Pandemic led to the closure of schools to enforce physical distancing measure, and this condition impact the refugee children learners as well. The study aims to examine legal protections of the right to education for the refugee childrenin international perspective and in Indonesia. This research usesa normative legal research using three approaches: statutory approaches, conceptual approaches, and comparative approaches. The result of this study was: the protection of the right to education towards the refugee children shall be remained a concern in international society. Education shall be applicable in a non-discriminatory manner, including to the refugee children. During this Covid-19 Pandemic, International organization as well as the States government shall ensure that the community as well as the refugee within certain state jurisdiction, remain informed about the educational opportunities, school re-opening and the pandemic. Secondly, Indonesia has no specific regulations about the implementation to the fulfillment of right to education towards refugee children. Whereas, Indonesia is responsible to provide non-discriminatory education to the children refugge. Thus, Indonesian government shall also put concern to the access to education especially during this Covid-19 Pandemic towards the refugee children.
\end{abstract}

Keywords: Refugee Children; Covid-19 Pandemic; Rights To Education

\section{INTRODUCTION}

The reflection of human rights violations is still being found in many parts of the world. The more astounding thing is when the highest number is found to be a violation of the rights of the child. According to Peter Davies, children become victims of various situations and conditions that are very concern.[1] The rise of abuse, child exploitation, discrimination, and various violent acts that endanger the physical, psychic, and social development of children is a form of transgression. The torture or persecution occurred due to intentional or otherwise accidental factors, or also because of the situation. Recorded in the past decade, about 1.5 million children were killed in armed conflict, 4 million children were leg defects or fractures, blindness and brain damage, 5 million children becoming refugees, and at least there were many more suffering from illness, malnutrition, and neglected education.[2]

Children as an integral part of the survival of human beings are very vulnerable. In fact, each child must be given a container to grow and develop to the fullest, both physical, mental, and social, to materialize the prospective successors of national and state life. On the other hand, every child should also be given special protection especially in the early years of his life that relies heavily on the existence of an adult.[3]Therefore, it needs a protection effort to realize the welfare of the child by providing assurance of the fulfillment of rights without any discriminatory treatment.

In general, the protection of human rights are manifested in several international instruments, from the Universal Declaration of Human Rights, International Covenant on Civil and Political Rights, International Covenant on Economic, Social and Culture, the Convention on the Rights of the Child, and some others convention. [4] In regards to the protection of children's right, the Convention on the Rights of the Child (CRC), which entries into force in 2 September 1990, becomes the main legal basis that 
offers the highest standards of protection and assistance for children. The main guiding principles for the CRC are non-discrimination, the best interest of the child, the right to life, survival and development, and the right to participation. [5]

The Human Rights conceptthat is grown by adults essentially also applies to children of equal value. It means to respect the child's rights as well as respect for human rights.[6] Philips C. Jessupaffirmed human Rights (HAM) is a priority in the importance of being under the international guarantee in the Charter of the United Nations so that all members of the UN cannot be backing on the importance of human rights issues.[7]

The birth of the child's right of thought was triggered by the reaction to the sufferings suffered by women and children after World War I. At that time, many children were orphaned by war. On the other hand, the rapid dynamics of the international community development in science and technology, especially transportation technology, give the victims the opportunity to move from country to country to seek protection. Refugees who come to a specific region of the country are usually family groups who are mature and who are still in the category of children so that the refugees of these children need attention and protection that is special in remembrance of the vulnerabilities they have.[8]Consequently, the protection of children is not only applied to the children of an Indonesian citizen but all children who inhabit the country of Indonesia.

Indonesia has ratified the CRC on 25 August 1990 through Presidential Decree No. 36 the Year 1990 (Government Gazette year 1990 number 57). Indonesia as the earliest state ratifying the CRC was to contribute to providing child protection. So Indonesia has the obligation to make various efforts in the protection of human rights. [9]To enforce the provisions under CRC, precisely on 22 October 2002, Indonesia established Law No. 23 of 2002 on the Child Protection. In its development, the law was amended by the Law Number 35 of 2014. Article 59 section (2) of the Law Number 35 of 2014 provides that the government, local government and other state institution shall be responsible to the "Special Protection" towards the "children". Article 59 section (2) provides provision on the subject who may receive this "special protection", and in its sub-section letter a provides that the special protection shall be provided to the children in emergency situation. Furthermore, article 60 provides that the children in emergency situation consist of the children who becomes refugee, children as the victim of riot, children as the victim of natural disaster, and the children in the situation of an armed conflict.

Based on the articles aforementioned, Indonesia has shown the effort in providing the right protection towards the refugee children. Disregard the fact that Indonesia has not ratified the 1951 Refugee Convention and 1967 Protocol, Indonesia still shall be liable for the right protection of the refugee childrenunder article 22 of the CRC.[10]Under the CRC, Indonesia shall undertake all appropriate legislative, administrative and other measures for the implementation of the rights recognized in the CRC. The protection standard under the $\mathrm{CRC}$ includes the guarantees of health, education and welfare, and include guarantees relating to the child's individual personality, rights to freedom of expression, religion, association, assembly, and privacy. Among others basic children's right, education becomes one of the most crucial rights to be fulfilled. As the refugee children are the vulnerable subject, education may protect them from child labor, sexual exploitation, child marriage, forced recruitment into armed groups. Further, education empowers them by the knowledge and skills to live productive and independent.[5]

In 31 December 2016, Indonesia established the Presidential Regulation Number 125 of 2016 concerning the Handling of Refugees from Abroad. This regulation is a part of the government's effort in handling the issue of refugee, even though there is no particular provision govern about the education of refugee childrenin the Regulation.[11] This is an interesting issue, since Indonesia has not ratified the 1951 Refugee Convention and the 1967 Protocol, but provides a national regulation regarding handling the refugee, even though it does not specifically govern about the right to education for the refugee children.

The UNHCR data shows, until June 2020, there are 13.541 refugees registered with UNHCR, and $28 \%$ (3.736 refugees) of which are children.Refugee children are indeed vulnerable subject. Moreover, since the Covid-19 has been determined as the global pandemic, it also impacts to the refugee as well as to the refugee children in terms of access to education.

Therefore, it is interesting to discuss about the fulfillment of the right to education towards refugee children especially during Covid-19 Pandemicboth 
from international perspective and in Indonesia. The refugee children themselves are vulnerable, even more during this current pandemic. During this pandemic, these children shall face problems from the communication language skill, education facilities and infrastructure, to the physical distancing policy that affect their access to education.

\section{PROBLEMS}

The problems of this research include first, How is the protection of the right to education towards refugee children during Covid-19 Pandemic? And, second, How is theprotection of the right to education towards refugee children in Indonesia?

\section{RESEARCH METHOD}

In this research, the author performs a normative legal research, which is the research conducted on the principles of law, the rules of law in the sense of value (norm), regulation of the law of concrete and system of law, with respect to the material being researched.

[12] The approach to the problem used is as follows:

1. The Statue approach, which is an approach through the study of all laws and regulations relating to the problems discussed. This method of approach requires understanding the hierarchy and the principles in the legislation.

2. Conceptual approach, which is an approach through assessment or concept of experts related to the discussion. It is done when the law does not exist.

3. Comparative approach, namely approach with the comparison of the law either sourced from another country or a certain time with another time. [13]

While the selected data collection techniques are documentation studies by noting any information relating to a topic that is selectively researched, then the prescriptive analysis means analyzing the documents by participating in the correct argument or one of the events in the eyewear. To get the answer to the problem examined through systematic, logical and sequential reasoning of the law by describing the legislation with international rules relating to the protection of therefugee childrens' right to education, especially during Covid-19 Pandemic.

\section{IV.DISCUSSION}

\section{IV.1. The Protection of the Right to Education for Refugee children during Covid-19 Pandemic in International Perspective.}

The refugee child is a very vulnerable group that needs to be given protection and special treatment. Peter Newel gives subjective reasons why children need protection, including: (i) Recovery fee; (ii) The long-term influence of actions or otherwise of the Government or a group of people; (iii) The gap in public service provision; (iv) The existence of voting rights not accompanied by lobbying ability to influence government policy; (v) Difficulty in accessing the protection and arrangement of children's rights; (vi) is often exploited and misused against the existing regulations.[14]

Lord Mc Dermont voiced "paramountcy means more than that child's welfare is to be treated as the top item in a list of terms relevant to be matter in question..." meaning that the welfare of the child is the main goal of every action, policy, and rule made by the competent authorities in which it is in line with the principle of the best interest of the child. [15] In precarious situations, child refugees are vulnerable to separate families. These children are then faced with greater risk of being recruited to become an army or sexually exploited or become victims of international crime-class human trafficking. [16]. So the children suffered from trauma and disturbance from the runaway. The second magazine preached Rohingya refugees as a real form of understanding the interconnectedness of universally inherent rights due to the large number of refugee children who were stranded in the Indonesian territory.[17]

In general, the protection of children has been a major concern marked by the ratification of the CRC, with 4 (four) principles in the Convention: (i) Nondiscrimination inspired in the universality principles of human rights; (ii) The best interest of the child, every action that is best for the child should be considered; (iii) Survival and development; (iv) Respect for the views of the child.The issue of nondiscrimination is significant for the refugee children. It is related to the recognition to be given the opportunity to enjoy the rights without regard to immigration status, citizenship or any other status. The rights in CRC shall be equally applicable to the refugee children as well as aliens.[5] The Committee on the Rights of the Child pointed out, "The 
Committee notes that all children who have had their asylum requests rejected but remain in the country have had their rights to health care and education provided de facto but not de jure. It is the view of the Committee that such services should be provided as a matter of principle according to the letter and spirit of article 2 and 3 of the Convention.'[5]

Furthermore, the Committee asserted that, "...with respect to the provision of health and education services to children in asylum-seeking situations, the Committee wishes to draw attention to the provisions of Article 2 of the Convention which state, inter alia, that States Parties shall respect and ensure the rights set forth in the present Convention to each child within their jurisdiction." [5]

The grant of refugee children rights to education shall remain be the concern even during this Covid-19 Pandemic. The spread of the Covid-19 Pandemic led to the total or partial closure of schools to implement a physical distancing protocol in order to eliminate the spread of the virus. As of Mid-June 2020, UNESCO reports that over $67,7 \%$ (around 1,18 billion learners) of all those enrolled in education programs are affected by the closures. This condition also impacts the refugee children who also as the leaners and students. During this pandemic, both refugee children learners and the teachers shall adapt a new learning mechanism to ensure the continuity of learning process. [18]

A lesson learnt from the Ebola crisis in 2014 2016 was the significance of ensuring that communities remain informed about educational opportunities, school re-opening and the epidemic.[18] Another lesson drawn from the other pandemic is to avoid the situation where the extended closure of schools led to the less likely return of the girls to school, even more, at a greater risk of falling behind.[19]

In response to the Covid-19 Pandemic, it is important to ensure the community as well as the refugee within state jurisdiction, remain informed about the educational opportunities, school re-opening and the pandemic. Thus, even though the Covid-19 impact on the closure of schools, the learning process still shall be maintained. In regards to this learning maintenance, some States as well as international organization undertake certain measures in response to the Covid-19 Pandemic by upholding and guaranteeing the right to education for refugees through ensuring all are able to learn at home and safely return to school. [20] Furthermore, most schools and universities establish an online learning mechanism and provide virtual learning.

Condition in Malawimay probably become a good example who undertake effort to maintain the access to education for the refugee children. The protection of right to education in terms of the Covid-19 Pandemic in Malawi are at least in the form of supporting teachers to adapt to new ways of teaching, providing hardware necessary to access learning program, ensuring the continuity of school-based support services.UNHCR and Jesuit Refugee Services (JRS) provided training to nine primary school teachers on the fundamentals radio broadcasting to support learning and deliver lessons using community radio. The Ministry of Education Science and Technology (MoEST) in Malawi initiated the Primary Emergency Radio Education Program. In this regard, UNHCR Malawi distributed 500 radios to primary students to enable them listening to the lessonsbroadcasts from the MoEST Porgram.[18]

In Malaysia, disregard its non-ratification of 1951 Refugee Convention status of the State, UNCHR partners distribute learning materials and worksheets to the refugee families together when they deliver food assistance for them. The completed worksheets are then collected and replaced with the new ones.[18]

\section{IV.2.The Protection of the Right to Education for Refugee children during Covid-19 Pandemic in Indonesia}

The 1945 Constitution as the foundation of Indonesia lists the child in one of its own. To follow up with the Constitution, on 22 September 2002 passed law Number 23 the year 2002 on Child Protection which was then amended by the Law Number 35 of 2014. Tb.Rachmat Santika mentions the fundamental points of this regulation, namely the fulfillment of children's rights to live, grow, develop and participate fully in accordance with dignity and respect and to obtain protection from the nature of discrimination and all forms of violence for the establishment of qualified generations. In terms of participation in development, recognition of the child's right to express opinion becomes the primary basis. [21]

As a member of the United Nations, in regards to the refugee children, Indonesia only ratifies the Convention on the Rights of children while the 1951 Convention on the Status of refugees and protocols 
1967 has not been ratified. Therefore, the fulfillment of the mandate of refugee protection and all its problems are handed over to the institution named UNHCR. Reading each article by article in the UNHCR statue is not explicitly attached to the child's refugees, although the term any person is categorized in children.

In fact, Indonesia recognizes the existence of children's rights characterized by the adoption of the Declaration of the Rights of children into Presidential Decree No. 26 of 1990. It means that Indonesia approves all contents of the Convention relating to the child in Indonesia as stipulated in article 3 paragraph 2 of the State's obligation to protect the child in its legal jurisdiction.To view its development in the field, the child's legal protection efforts are limited to children in need of special protection such as children who are in emergency situations as written in article 59 of Law No. 23 of 2002. In addition, it can be seen in article 60 point $A$ of the child being a refugee. This is very difficult because until this second Indonesia does not have a written legal arrangement against the protection of Refugees as stated in the 1951 Refugee Convention. However, it should be underlined that the benchmark of human rights implementation is not limited to the ratification of international treaties. This can certainly be done if the national law has covered all the concerns. [22]

Damos Dumoli Agusman mentions the process of ratification can not be done plainly, because the true ratification is done according to the needs, demands, and in accordance with the development of the people of Indonesia. [23] On the other hand, the international world continues to urge to ratify the conventions pertaining to human rights. However, the Indonesian government has a different way than to ratify the Convention, by farming the opening of the Constitution of the year 1945 which reads "... To form a government of Indonesia that protects all Indonesians and all the blood in Indonesia. To conduct a world order based on independence, eternal peace, and social justice." So it is guided by the opening of this Constitution is evidence of Indonesia participated in the enforcement of human rights.

Ratification of the Refugee Convention and its Protocol is not a fault, even Komnas HAM presents two advantages if Indonesia ratified this Convention, "First, the government can determine the status of refugees as a form of direct involvement in the handling of issues of national interest. Secondly, the government is getting help and international cooperation in the handling of refugees and asylum seekers. The expenses borne by the State are not entirely government-imposed but also by the international community." [24] The handling of refugee problems that have been the duty of UNHCR at least get supervision from the direct government if there are persons who utilize refugees committing international crimes. This is because UNHCR as an authorized institution cannot refuse if there is a refugee in need of protection but on the other hand, Indonesia has difficulty dampening in case of international offense within its country, because Indonesia is not a country that supports 1951 Refugee Convention.

In the case of human rights, enforcement should not wait for adjustments between people's needs in protecting refugees in the absence of a clear arrangement for it. Only, in the implementation will be clash and limited if the arrangement is not only the right of child rights while the intended child is not merely a genuine Indonesian child but all children in Indonesia in this case also the child of refugees. Article 22 of the CRC requires the State to ensure appropriate protection and humanitarian aid. The state is also required to guarantee every institution of service and facilities as per the standards created by the competent child agencies as stated in article 3 paragraph (3) of the Child Rights Convention.

Based on the UNHCR fact sheet on June 2020 edition, Indonesia has provided refugee children access to national schools through the Ministry of Education Circular Letter No. 75253/A.A4/HK/2019 issued on July 2019. [25] In 2019, Pekanbaru Education Authorities prepared 12 public schools for the refugee children. [26] However, the refugee children may still find difficulties in having access since there is no particular regulation granting the access to education for refugee children. [11]

During the Covid-19 Pandemic, as of June 2020, there is no reported case of refugee who suffer the Covid-19. On the other hand, to minimize the risk of the virus spread, Indonesian government has delayed all formal as well as non-formal education activities, and switched to distance learning delivered through free online educational platforms, such as radio and TV lessons broadcasting. Moreover, the Ministry of Education also collaborated with three major telecommunications operators providing free internet 
data to access online education platforms. Most learning centers established by UNHCR Indonesia and its education partners, moved to distance learning mechanism using video conferencing application such as Zoom or YouTube and instant messaging application such as WhatsApp. [18]

Until now, Indonesia has no specific regulations about the implementation to the fulfillment of right to education towards refugee children.Indonesian government only relies on the Presidential Regulation No. 125 of 2016 concerning the Handling of Refugees from Abroad. Even so, Indonesia has undertaken measures to equip the refugee with information and self-protection tools. [27] However in regards the rights to education towards refugee children during Covid-19 Pandemic, Indonesian government shall put concern to the access to education, such as the hardware in having an online learning, and the network as well as the upgrading of teacher's capability.

\section{CONCLUSION}

In conclusion, the protection of the right to education towards the refugee children shall be remained a concern in international society. Education shall be applicable in a non-discriminatory manner, including to the refugee children. During this Covid19 Pandemic, International organization as well as the States government shall ensure that the community as well as the refugee within certain state jurisdiction, remain informed about the educational opportunities, school re-opening and the pandemic.

Under article 22 of the CRC, Indonesia shall be responsible to provide the non-discriminatory access to education towards the refugee children. Furthermore, the Law No.35 of 2014 concerning the Amendment of the Law No. 23 of 2002 concerning Child Protection affirm Indonesian obligation to provide special protection to the refugee children within Indonesian jurisdiction. In general, Indonesia has taken some measures to ensure the fulfillment of the right to education. However, in regards to the protection of the right to education towards refugee children during Covid-19 Pandemic, Indonesian government shall also put special concern to the access to education, such as the hardware for the refugee children in having an online learning, and the network in certain area, as well as the teacher's capability upgrading.

\section{ACKNOWLEDGEMENT}

We would like to thank to the Faculty of Law University of Ahmad Dahlan and allparties who have assisted in finishing this paper.

\section{REFERENCES}

[1] P. Davies. Human rights, Jakarta: Indonesian Torch Foundation, 1994

[2] J. P. Grant. The world's children's situation, the UNICEF representative office for Indonesia, Jakarta, 1994

[3] C. D. Rover. To Serve \& To Protect Universal Human rights enforcement. Jakarta: PT Raja Grafindo Persada, 2000.

[4] UNESCO. Protecting the Right to Education for Refugees. Working Papers on Education Policy, Second Edition, France: UNESCO Organization, 2017.

[5] U. Refugees, "Action for the Rights of Children (ARC): Foundations - International Legal Standards", UNHCR, 2020. [Online]. Available: https://www.unhcr.org/3e37e5ba7.pdf.

[Accessed: 29- Aug- 2020]

[6] S.S. Hadiwijoyo. Child Rights Mainstreaming in Public Budget, Yogyakarta: Graha ILMU, 2015

[7] P. C. Jessup, A Modern Law of Nations (Introduction to Modern Law), interpreting: Fitria Mayasari. Bandung: Nuansa Cendekia , 2012.

[8] Fita Erdiana. Protection Of The Law For Refugees From Armed Conflict In The Democratic Republic of The Congo According To International Refugee Law, Surakarta: Tesis Universitas Sebelas Maret, 2009.

[9] R.K.M. Smith \& C. Ranheim. Human Rights Law, Yogyakarta: PUSHAM UII, 2008.

[10] M. Riadhussyah, "PERLINDUNGAN HUKUM BAGI PENGUNGSI ANAK DI INDONESIA MENURUT HUKUM INTERNASIONAL", Hukum.studentjournal.ub.ac.id, 2020. [Online]. Available:

http://hukum.studentjournal.ub.ac.id/index.php/h ukum/article/view/1745/1300. [Accessed: 29Aug- 2020]

[11] F.B. Anggoro. "Polemik menyekolahkan pengungsi anak di SD negeri di Pekanbaru", Antara News, 2020. [Online]. Available: https://www.antaranews.com/berita/928503/pole 
mik-menyekolahkan-pengungsi-anak-di-sdnegeri-di-pekanbaru. [Accessed: 29- Apr- 2020]

[12] S. Mertokusumo. Penemuan hukum, Yogyakarta: Liberty, 2004.

[13] P.M Marzuki. Penelitian Hukum, Jakarta: Pranada Media Group, 2014

[14] M. Nasir Djamali, The child not to be punished (note the discussion of the children's criminal justice system ACT), Jakarta: Sinar Grafika 2014.

[15] S. Goonesekere, Children, Law and Justice a South Asian Perspective, New Dehli: UNICEF, 1998.

[16] "Humanitarian Aid Organization for Children", Save the Children, 2020. [Online]. Available: https://www.savethechildren.org/. [Accessed: 03- Jan- 2020].

[17] M. Wibisono. the Rohingya dilemma Jakarta: (magazine seconds edition 1-7 June 2015), 2015.

[18] UNHCR. Supporting Continued Access to Education during Covid-19: Emerging Promising Practices. UNHCR Education Section, July Edition, Issue 2, Pg. 2. [Onnline] Available: https://www.unhcr.org/5f06d92e4.pdf, 2020

[19] J. Hallgarten, "Evidence on efforts to mitigate the negative educational impact of past disease outbreaks", Reliefweb.int, 2020. [Online]. Available:

https://reliefweb.int/sites/reliefweb.int/files/resou rces/793_mitigating_education_effects_of_disea se_outbreaks.pdf. [Accessed: 29- Aug- 2020]

[20] UNESCO, "Latest articles", UNESCO, 2020. [Online]. Available: https://en.unesco.org/news/covid-19-what-youneed-know-about-refugees-education.

[Accessed: 29- Mar- 2020].

[21] Tb. Rachmat Sentika, The Role of Humanity In Improving Indonesian Human Quality Through Child Protection In Order To Realize Healthy Indonesian Children, Smart Cheerful, Noble And Protected, Bandung: Sociotechnology Journal.Edition II, 2005

[22] S.B Amidjojo. (2004). Legal Protection Against Refugees Based On Geneva Convention 1951, Jakarta: National Legal Development Agency Department of Law and Human Rights RI, 2004.

[23] D.D. Agusman, international treaty Law of Theory and Practice studies in Indonesia, Bandung: Refika Aditama, 2014
[24] Online Law, Indonesia needs the ratification of the Convention on Refugees, many evacuees who neglected its rights in the immigration Detentions House, [Online] Available: www.hukumonline.com, [Accessed 3-January2020]

[25] UNHCR. Indonesia Fact Sheets - June 2020, Pg. 1. [Online] Available: https://www.unhcr.org/id/wpcontent/uploads/sites/42/2020/08/IndonesiaFact-Sheet-June-2020-FINAL.pdf, 2020

[26] R. Pos, "Tak Ada Aturan Izin Anak Imigran Bersekolah", RiauPos.co, 2020. [Online]. Available: https://riaupos.jawapos.com/pekanbaru/02/07/20 19/202721/10-kategoriberita-pendidikan.html.

[Accessed: 29- Aug- 2020]

[27] I. Hidayati, Pengungsi di Tengah Pandemi COVID-19,Pusat Penelitian Kependudukan LIPI,[Online] Available: https://kependudukan.lipi.go.id/id/berita/53mencatatcovid19/984-pengungsi-di-tengahpandemi-covid-19, 2020. 